\title{
The Duty to Cooperate
}

\section{The Fund's Role and Cooperation among States}

This chapter examines the duty to cooperate internationally as the best solution to solve the problems associated with Common Concerns. Recognising that there is no general duty to cooperate, consult and negotiate under current international law, this duty would apply only to matters that are considered Common Concerns of Humankind. This proposed duty to cooperate under the emerging doctrine of Common Concern would entail an improved transparency in information sharing and the timely and accurate publication of laws and regulations. It would also involve the duty to consult and negotiate to reach a consensus. The discussions will surround the issue of the burden-sharing among parties and the shared but differentiated responsibilities of the actors involved in the specific subject matter. ${ }^{1}$

Concerning monetary affairs and as presented elsewhere in this book, since the collapse of the 'Bretton Woods System'2 in the 1970's the role of international public law and international institutions is limited. Thus, international cooperation for the pursuit of monetary stability lacks an appropriate international regulatory framework and instead rests on soft governance arrangements and mostly on the good-will of the states to promote monetary policy coordination among the central banks. Consequently, Common Concern if established as a principle, aims to enhance the duty to cooperate in monetary affairs both from a top-down approach and a bottomup approach. While the top-down approach relates to the duty to cooperate at the international level of governance with the International Monetary Fund (IMF or the Fund) as the central international monetary institution, the bottom-up approach considers the cross-border cooperation among countries with a special emphasis on monetary policy coordination among central banks.

\footnotetext{
1 Thomas Cottier, 'The Principle of Common Concern of Humankind' in Thomas Cottier (ed) 'The Prospects of Common Concern of Humankind in International Law' (CUP 2021).

2 As described in chapter 1 , section 3 of this book.
} 
Notwithstanding the indisputable fact that monetary stability is a sovereignty issue, it also has an international dimension. This global dimension refers to the stability of the international monetary system (IMS) as a whole. According to the Fund's view, ${ }^{3}$ the stability of the IMS refers to the stability of the overall system of exchange rates in accordance with the purpose of the Fund as stated in the Article I(iii) of the Articles of Agreement of the International Monetary Fund (Articles of Agreement), that is, 'To promote exchange stability, to maintain orderly exchange arrangements among members, and to avoid competitive exchange depreciation'. ${ }^{4}$

However, the stability of the IMS goes beyond stability of exchange rate agreements. It also depends on the stability of the other key elements of the system. These are, as explained in detail in chapter 1 of this book, the four core elements of the IMs: exchange rates, international payments system, international capital movements, and monetary reserves and access to liquidity. Moreover, the stability of the IMS is intrinsically related to the stability of the international financial system despite them being two different systems. ${ }^{5}$ Hence, the international level of governance from a top-down approach considers the IMS as being an integral part of the so-called global or international financial architecture (IFA). ${ }^{6}$

3 IMF, 'Modernizing the Legal Framework for Surveillance - An Integrated Surveillance Decision' (July 2012) <www.imf.org/external/np/pp/eng/2012/o71712.pdf> accessed 21 October 2021.

4 The Articles of Agreement of the International Monetary Fund (Articles of Agreement) were adopted as a result of the United Nations Monetary and Financial Conference, Bretton Woods, held in New Hampshire, United States of America, on 22 July 1944 and were entered into force on 27 December 1945. They were amended on six occasions. IMF, 'Articles of Agreement of the International Monetary Fund' <www.imf.org/external/pubs/ft/aa/ $>$ accessed 21 October 2021.

5 Janet Yellen, former chair of the Fed, provides a definition that distinguishes the two systems: The international monetary system is the set of rules, conventions, and institutions associated with monetary policy, official capital flows, and exchange rates. It also includes mechanisms to provide official sector support to countries facing funding pressures. The international financial system is much broader, encompassing both private and official participants in global financial markets.

Janet Yellen, 'Improving the International Monetary and Financial System' (Banque de France International Symposium, Paris, 4 March 2011) <https://www.federalreserve.gov/new sevents/speech/files/yellen20110304a.pdf> accessed 21 October 2021.

6 Christian Tietje, 'The International Financial Architecture as a Legal Order' (2011) 54 German Yearbook of International Law (2011). 
Since the breakdown of the 'Bretton Woods' system in the 1970's and the consequent end of the par-value system, the international financial markets experienced a significant expansion. This development was triggered mostly by the liberalisation of finance brought by the elimination of exchange restrictions, the introduction of convertible currencies and the expansion of private capital flows. In this context, between the 1970's and the 1980's, the IFA started to develop with central banks playing a crucial role in the management of the international monetary and financial systems, intergovernmental groups of countries, such as the Group of Ten (G10), taking the lead on political processes and other international bodies issuing international standards to cover the absence of international financial regulation. ${ }^{7}$ Most notably, the Basel Committee on Banking Supervision (всв) ) was established after the collapse of several important banks in 1974 (Herstatt Bank in Germany, British-Israel Bank in Tel Aviv and London and Franklin National Bank in New York and London) as one of the leading international financial standard-setting bodies. ${ }^{8}$

Despite the lack of consensus on the notion of IFA, most of the definitions provided by the literature on IFA involve normative and institutional aspects. A first attempt at definition was provided by Mario Giovanoli in 2000: 'This concept is generally understood as encompassing the rules, guidelines, and other arrangements governing international financial relations as well as the various institutions, entities and bodies through which rules, guidelines and other arrangements are developed, monitored and enforced. ${ }^{9}$ Later on, Andrew Crockett reflects in 2010 that the IFA comprise of three interrelated elements: 'first, the basic economic model that governs cross-border monetary and financial relations; second, the institutional structure that exists to

7 For an extended description of the evolution of the IFA see Annamaria Viterbo, International Economic Law and Monetary Measures: Limitations to States' Sovereignty and Dispute Settlement (EE 2012) ch 3; Claus D Zimmermann, A Contemporary Concept of Monetary Sovereignty (OuP 2013) ch 5; Rosa M Lastra, International Financial and Monetary Law (2nd edn, OUP 2015) ch 14.

8 The всвS, with headquarters at the Bank for International Settlements (вIS) in Basel, Switzerland was established to enhance financial stability by improving the quality of banking supervision worldwide and to serve as a forum for regular cooperation between its member countries on banking supervisory matters. Detailed information on the вСвs is available at its official website $<$ www.bis.org $>$. On the history and development of the всвS see Gianni Toniolo, Central Bank Cooperation at the Bank for International Settlements 1930-1973 (CUP 2005); Charles Goodhart, The Basel Committee on Banking Supervision: A History of the Early Years 1974-1997 (CUP 2011).

9 Mario Giovanoli, 'A New Architecture for the Global Financial Markets: Legal Aspects of International Financial Standard Setting' in Mario Giovanoli (ed), International Monetary Law: Issues for the New Millennium (oup 2000) 9. 
manage and, where necessary, adapt these relations; and third, the distribution of decision making authority in international institutions.' ${ }^{10}$ In this chapter I consider both the institutional aspect of the IFA that relates to the governance structure and the main actors that are involved with it and the normative aspect of the IFA that is based on a system of international standard-setting (mostly soft-law).

\subsection{The International Financial Architecture - Governance Aspects}

As noted by Giovanoli, the term international financial architecture or IFA appeared in 1999 as a result of the financial crises experienced during the 1990's. ${ }^{11}$ In particular, Giovanoli remarks that the Asian crisis provoked the formation of the Group of $20(\mathrm{G} 20)^{12}$ and the Financial Stability Forum $(\mathrm{FSF})^{13}$ succeeded later by the Financial Stability Board (FSB) with the aim to coordinate the diverse standard-setting bodies and reduce regulatory and supervisory gaps at domestic levels that may threaten systemic stability. Notwithstanding the international community's efforts to coordinate and harmonise global financial standards within the IFA framework, the global financial crisis of 2007-2009 (GFC) ${ }^{14}$ uncovered some serious deficiencies.

As also observed by Giovanoli, these shortcomings revealed by the GFC were not only related to the design and functioning of the international financial system but also to flaws in domestic regulation and supervision. ${ }^{15}$ Consequently, a profound restructuring of the IFA was called upon together with a regulatory reform agenda under the purview of the G2O. The G2O, which was mostly inactive since its creation in 1999 until the onset of the GFC (with the exception of the annual meetings of central bank governors and finance ministers), assumed a key role as the leading forum for international economic

10 Andrew Crockett, 'What Have We Learned in the Past 50 Years about the International Financial Architecture?' (Reserve Bank of Australia 5oth Anniversary Symposium, Sydney, February 2010) <www.rba.gov.au/publications/confs/2010/pdf/crockett.pdf> accessed 21 October 2021.

11 Mario Giovanoli, 'The International Financial Architecture and its Reform After the Global Financial Crisis' in Mario Giovanoli and Diego Devos (eds), International Monetary and Financial Law: The Global Crisis (oup 2010) 3.

12 For more information about the G2O visit the official website at <https://g2o.org/en/sum mit/about/> accessed 21 October 2021.

13 Visit the FSB website for comprehensive details of the history and functioning of the body $<$ www.fsb.org/about/> accessed 21 October 2021.

14 See Rosa M Lastra and Geoffrey Wood, 'The Crisis of 2007-2009: Nature, Causes, and Reactions' (2012) 13 JIEL 531.

15 Giovanoli, 'The International Financial Architecture' (n 11). 
cooperation, directed by the decisions taken during the 'Leaders' Summits' held in November 2008 (Washington Summit) and April 2009 (London Summit).

At the Washington Summit of November 2008 the G2o Leaders designed an action plan with the view to implement the five agreed principles for the reform of the IFA. Those principles are: strengthening transparency and accountability, enhancing sound regulation, promoting integrity in financial markets, reinforcing international cooperation and reforming international financial institutions. ${ }^{16}$ The London Summit of April 2009 gave a boost to the IFA reform by strengthening the international financial institutions, particularly by increasing the resources available to the IMF and establishing a new FSB with a strengthened mandate, as a successor to the FSF. ${ }^{17}$ These 'Leaders' Summits' continue to be held on an annual basis (with two meetings held during 2009 and 2010). Most of the financial regulatory and supervisory reforms endorsed by the G2O at its various Leaders' Summits have been extensively analysed and covered by the existing literature. ${ }^{18}$ Hence, this chapter does not observe those initiatives and only examines the governance and normative aspects of the IFA.

The main actors in the reformed IFA have been categorised by Lastra in two big groups. ${ }^{19}$ On the one hand 'formal' international organisations and on the other hand 'informal' international groupings. Under the first category there are international financial institutions formally recognised by treaty, including both multilateral organisations and regional institutions and also international forums that meet under the aegis of any of these formal organisations (like the FSв and the всвS under the auspices of the вIS in Switzerland). The key multilateral organisations under the IFA are: the IMF, the World Bank Group, the BIs, the Organisation for Economic Co-operation and Development

16 Group of 20, 'Declaration Summit on Financial Markets and the World Economy' (15 November 2008) <www.mofa.go.jp/policy/economy/g2O_summit/2008/declaration. pdf\#action> accessed 21 October 2021. Viterbo observed that 'Many of the measures identified by the G2O as necessary to overcome the crisis - and prevent contagion - were implemented at national level and financed by government budgets'. Viterbo, International Economic Law (n 7) 113-114.

17 Group of 20, 'London Summit - Leaders' Statement' (2 April 2009) <www.mofa.go.jp/policy/economy/g2O_summit/2009-1/communique.pdf > accessed 21 October 2021.

18 Charles Goodhart, The Regulatory Response to the Financial Crisis (E 2009); Mario Giovanoli and Diego Devos (eds) International Monetary and Financial Law: The Global Crisis (oup 2010); Thomas Cottier, John H Jackson and Rosa M Lastra (eds), International Law in Financial Regulation and Monetary Affairs (OuP 2010); Dirk Schoenmaker, Governance of International Banking: The Financial Trilemma (OUP 2013); Thomas Cottier and others (eds), The Rule of Law in Monetary Affairs (CUP 2014).

Rosa M Lastra, International Financial and Monetary Law (n 7) 543-544. 
(OECD) and the World Trade Organization (WTO). The regional institutions comprise an array of diverse institutions such as the regional development banks (European Bank for Reconstruction and Development, Inter-American Development Bank, African Development Bank, Asian Development Bank) and other supranational institutions at the European and worldwide level. In the second category of 'informal' international groupings dealing with global financial and economic matters there are de facto groupings created by governments (like the Group of 7, Group of 10, G20), national central banks, finance ministers or treasuries meeting through their representatives in diverse formal or informal groupings and private financial institutions performing at a global level.

Adopting the comprehensive categorisation provided by Lastra, it can be stated, in line with Giovanoli's view, that the current IFA is led by three predominant and distinct entities: the IMF, the G2O and the FSB, as illustrated by the graphic attached as Annex I to this chapter. ${ }^{20}$ These three entities are different in their membership, mission and legal status.

The IMF, created in 1945, is an international organisation with almost universal membership (190 countries as of March 2021). The Fund's main purpose is to ensure the stability of the international monetary system and since 2012, when its mandate was updated, it also considers macroeconomic and financial sector issues that bear on global stability. The key functions of the Fund are surveillance, conditional financial assistance and technical assistance. It's based on a system of quotas and the resources are mainly provided by its members. ${ }^{21}$

The G20, launched in 1999, is an informal political forum composed of 19 member states and the European Union. The purpose of the forum is to strengthen international economic cooperation among members while overseeing the overall functioning of the IFA. The G2O is supported by international organisations, including the FSB, the IMF, the International Labour Organisation, the OECD, the United Nations, the World Bank and the wто. ${ }^{22}$

20 Brummer makes a differentiation among agenda-setters (G2O and FSB), sectoral and specialist standard-setters (BCS, IOSCO and OECD, among others) and the entities that monitor the system and compliance with the standards (IMF and the World Bank). Chris Brummer, Soft Law and the Global Financial System - Rule Making in the 21st Century (CUP 2015) 69 .

21 For detailed information about the Fund see 'About the IMF' <www.imf.org/en/About> accessed 21 October 2021.

22 For more information about the G2O see 'What is the G2O Summit?' < https://g20.org/en/ summit/about/> accessed 21 October 2021. 
The G2o Finance Ministers and Central Bank Governors created in April 2017 the G2o Eminent Persons Group on Global Financial Governance (the 'E PG'). ${ }^{23}$ The work of the EPG is centered around the following tasks: (1) to review current and possible future challenges and opportunities facing the international financial and monetary systems, and the current state of the global financial architecture and governance; (2) to consider the optimal role of the IFIs; and (3) to recommend practical reforms to improve the functioning of the global financial architecture and governance so as to promote economic stability and sustainable growth. The EPG will provide its findings and recommendations to G2o Finance Ministers and Central Bank Governors for their deliberation.

The FSB, established in 2009 as the successor to the FSF, is an international body that monitors and makes recommendations about the global financial system. Its membership comprises 24 countries, the European Union, international financial institutions (IFIs) and standard-setting bodies. The FSB promotes international financial stability; it does so by coordinating national financial authorities and international standard-setting bodies as they work toward developing strong regulatory, supervisory and other financial sector policies. $^{24}$

The improvements in the governance aspects of the IFA since the GFC have no doubt enhanced the institutional foundations. ${ }^{25}$ Notwithstanding that, it can be argued that the present IFA is based on the 'horizontal' cooperation of domestic regulators under the guidance of the G2o, as opposed to the institutional 'vertical' process of treaty-based international organisations. As pointed out by Viterbo, 'As the time was not ripe for a new multilateral agreement or for a swift reform leading to a greater role of the IMF in the financial sector, the strategy adopted was the reinforcement of the GFA, building on the existing structure. ${ }^{26}$ Consequently, some major challenges concerning the institutional legitimacy of the entities involved in the process of international

\footnotetext{
23 The EPG comprises eminent persons with deep knowledge and experience in the area of the global financial architecture and governance. For more information on the EPG see, $<$ https://www.globalfinancialgovernance.org/about-g2O-epg/> accessed 21 October 2021.

24 For more details about the FSB see 'About the FSB' <www.fsb.org/about/> accessed 21 October 2021. See also the recent paper by de Stefano who argues in favour of a further institutionalisation of the FsB Carlo de Stefano, 'Reforming the Governance of International Financial Law in the Era of Post-Globalization' (2017) 20(3) JIEL 509.

25 For a description about the improvements in the institutional aspects of the IFA in the aftermath of the GFC see Zimmermann, Monetary Sovereignty (n 7) 191. 
financial standard setting (IFS s) and the limits of the soft-law approach in IFS S remained unsolved. ${ }^{27}$

\subsection{The Fund's Role}

The regulatory function in global monetary affairs is shared by a number of formal and informal international standard-setters, including most notably the FSB and BIS as detailed in the previous section. However, this chapter asserts that the IMF maintains its lead as the central international monetary institution and is also at the centre of the IFA. ${ }^{28}$ The role of the IMF has changed since its origin, as pointed out by Lastra, 'Over the last few decades, the IM F's mandate has been broadened: from being primarily an international monetary institution to becoming an international financial institution, encompassing not only monetary issues but also other financial issues (capital markets, payment systems, etc)'.29

As part of the IFA reforms prompted by the GFC, the IMF members introduced two ambitious packages on the Fund's existing quotas and governance in 2008 and $2010 .{ }^{30}$ The IMF is a quota-based institution where each member is assigned a quota representing its position on the world economy and such quota determines the members' voting power, financial commitment to the Fund and access to IMF financing. ${ }^{31}$ The quotas are denominated in Special Drawing Rights (SDRs) as the unit of account. These far-reaching reforms aimed at enhancing the Fund's role in the promotion of global financial stability gave more influence to emerging and developing economies while also

27 Mario Giovanoli, 'The International Monetary and Financial Architecture - Some Institutional Aspects' in Thomas Cottier and others (eds), The Rule of Law in Monetary Affairs (CUP 2014) 45 .

28 As remarked by Zimmermann, 'Under the impact of the Global Financial Crisis, the Fund has finally come to realize that it is not possible to durably secure the stability of the international monetary system without also looking after the stability of the international financial system more broadly'. Zimmermann, Monetary Sovereignty (n 7) 217.

29 Lastra, International Financial and Monetary Law (n 7) 497.

30 The 2008 quota and voice reforms were approved on 28 April 2008 by the IMF Board of Governors and entered into force on March 2011. The 2010 reform package resulted from the 14th General Review of Quotas and was approved by the IMF Board of Governors on 15 December 2010. For detailed and updated information on these reforms see 'IMF Quota and Governance Publications' < www.imf.org/external/np/fin/quotas/pubs/index. htm $>$ accessed 21 October 2021.

31 The current quota formula is a weighted average of GDP (weight of 50 percent), openness (3o percent), economic variability ( 15 percent) and international reserves ( 5 percent). 'IMF Quotas' (4 March 2021) <www.imf.org/en/About/Factsheets/Sheets/2016/o7/14/12/ 21/IMF-Quotas> accessed 21 October 2021. 
preserving and enhancing the voice and participation of low-income countries. As remarked by Zimmermann, 'the major overhaul of IMF governance aimed at increasing the organization's credibility, legitimacy and effectiveness.' ${ }^{32}$

The entry into force of the Second Amendment to the Articles of Agreement in 1978 (Second Amendment) ${ }^{33}$ represents an inflection point from a rulebased system monitoring the 'par value' regime to a surveillance-based function. ${ }^{34}$ The Fund's main functions in relation to its members are established in the Articles of Agreement as surveillance (Article IV), financial assistance (Article v, Section 3) and technical assistance (Article v, Section 2(b)). While obligations relating to IMF's surveillance function are of a mandatory nature for all IMF members, obligations relating to financial assistance and technical assistance have a voluntary nature and are performed by the Fund only upon the member's request. ${ }^{35}$

The surveillance function is at the centre of the Fund's operations and provides the post Second Amendment raison d'etre of the IMF. ${ }^{36}$ This function enables the IMF to monitor compliance with standards and rules and to provide incentives for member states to comply with such standards and rules (through the design of conditionality policies). ${ }^{37}$ The legal basis of surveillance set forth in Article IV, sections 1 and 3 provides both obligations upon members and specific powers to the Fund to oversee and monitor the member's compliance with its obligations. In order to provide clear guidance on the surveillance

32 Zimmermann, Monetary Sovereignty (n 7) 227.

33 The Second Amendment to the Articles of Agreement came into effect on 1 April 1978, by the modifications approved by the Board of Governors in Resolution No. 31-4.

34 According to Guitián this surveillance-based function of the IMF is discretionary and thus judgement is of the essence. However, he also remarks that the discretion is limited by the code of conduct enshrined in the Articles of Agreement. Manuel Guitián, 'The Unique Nature of the Responsibilities of the International Monetary Fund' (1992) Pamphlet Series No 46 <https://imf.org/external/pubs/ft/pam/pam46/pam46con.htm> accessed 21 October 2021.

35 Moreover, as argued in chapter 6 of this book, the main obligations of the IMF member states under the amended Articles of Agreement are considered of 'soft' nature and would only require the 'best efforts' of the members with the exception of Article IV, Section 1(iii) regarding exchange rate manipulation.

36 IMF, The Fund's Mandate - An Overview (22 January 2010) <http://www.imf.org/exter nal/np/pp/eng/2010/o12210a.pdf> accessed 21 October 2021; IMF, The Fund's Mandate The Legal Framework (22 February 2010) <http://imf.org/external/np/pp/eng/2010/o22 210.pdf > accessed 21 October 2021.

37 Conditionality only applies to IMF member states that request for financial assistance from the Fund. 'IMF Conditionality' (2021) <www.imf.org/en/About/Factsheets/Sheets/ 2016/08/o2/21/28/IMF-Conditionality > accessed 21 October 2021. 
policies the Fund adopted specific principles of surveillance in a decision of April 1977, as replaced by a new decision of June $2007 .^{38}$

Also, beyond bilateral surveillance performed by individual countries, the IMF performs multilateral surveillance of the global economy, thus helping to identify the impact domestic policies may have on other countries and the global economy. ${ }^{39}$ Consequently, a new decision on bilateral and multilateral surveillance was adopted in July $2012 .{ }^{40}$ This new decision maintains the key principles of the 2007 decision on bilateral surveillance and adopts new principles for multilateral surveillance. As stated by Viterbo 'As monetary and financial stability are inextricably intertwined, the IMF is perfectly equipped to monitor "holistically" its members' macroeconomic and macrofinancial policies, as well as their linkages and implications for global stability'.41

The surveillance of rules and standards is done via consultations in accordance with Article IV of the Articles of Agreement, the Financial Sector Assessment Program (FSAP) and the Reports on the Observance of Standards and Codes (ROSC s). ${ }^{42}$ The FSAP comprises a profound analysis of a country's financial sector and is the joint responsibility of the IMF and World Bank in developing economies and emerging markets and the sole responsibility of IMF in advanced economies. ${ }^{43}$ ROSC s are a crucial part of the FSAP because they summarise the extent to which countries observe certain internationallyrecognised standards and codes. ${ }^{44}$ As pointed out by Lastra, both FSAP and

38 Decision of the Executive Board No 5392-(77/63) of 29 April 1977 as replaced by the Decision of the Executive Board of 15 June 2007. See 'Bilateral Surveillance over Members' Policies' (21 June 2007) < www.imf.org/en/News/Articles/2015/o9/28/04/53/pno769\#decision> accessed 21 October 2021.

'IM F Surveillance' (2021) < www.imf.org/en/About/Factsheets/IMF-Surveillance> accessed 21 October 2021.

40 IMF, 'Modernizing the Legal Framework for Surveillance' (n 3). The 2012 Integrated Surveillance Decision has been reviewed and further developed as part of the 2014 Triennial Surveillance Review (TSR) and the 2018 Interim Surveillance Review (ISR), and will be again comprehensively assessed in 2020 as part of the Comprehensive Surveillance Review (CSR). 'IMF Surveillance' (2021) < www.imf.org/en/About/Factsheets/ IMF-Surveillance $>$ accessed 21 October 2021.

41 Viterbo, International Economic Law (n 7) 112.

42 For a detailed study on ImF surveillance see Nadia Rendak, 'Monitoring and Surveillance of the International Monetary System: What can be learnt from the trade field?' in Thomas Cottier and others (eds), The Rule of Law in Monetary Affairs (CUP 2014) 204.

43 Financial Sector Assessment Program (FSAP)' (2021) <www.imf.org/en/About/ Factsheets/Sheets/2016/o8/o1/16/14/Financial-Sector-Assessment-Program > accessed 21 October 2021.

44 The IMF has recognised 12 areas and associated standards as useful for the operational work of the Fund and the World Bank. These comprise accounting; auditing; anti-money laundering and countering the financing of terrorism (AML/CFT); banking supervision; 
ROSC s are performed as part of the technical assistance functions of the Fund with the purpose of informing its surveillance function. ${ }^{45}$ These activities are voluntary with the exception of those jurisdictions considered systemically important based on the size and interconnectedness of their financial sectors. ${ }^{46}$ According to the latest annual report to the G2O on the implementation and effects of reforms issued by the FSB in November 2018, all of FSB's jurisdictions have now published their financial system stability assessment reports and the results of their standards compliance assessments in FSAP s. ${ }^{47}$

The second main function of the Fund, financial assistance, is performed through the provision of financing to countries with balance of payments difficulties upon their request. ${ }^{48}$ The aim is to provide temporary financing and to support policies aimed at correcting underlying problems. The IMF's various lending instruments are custom-made to different types of balance of payments problems as well as the specific conditions of its different members. The Fund's lending usually requires a country's commitment to undertake certain policy actions, known as policy conditionality. Lending to low-income countries are particularly directed at poverty reduction. ${ }^{49}$

The third key function performed by the Fund is the provision of technical assistance to its members upon their request. The aim is for the Fund to work jointly with the members in order to fortify their economic institutions by offering technical assistance and training on crucial economic issues, such as public financial management, tax policy and administration, banking supervision, monetary and exchange rate policy, official statistics and legal issues.

corporate governance; data dissemination; fiscal transparency; insolvency and creditor rights; insurance supervision; monetary and financial policy transparency; payments systems; and securities regulation. 'Reports on the Observance of Standards and Codes (ROSC s)' (21 June 2019) <https://www.imf.org/external/NP/rosc/rosc.aspx> accessed 21 October 2021.

45 Lastra, International Financial and Monetary Law (n 7) 462.

46 In December 2013, the IMF's Executive Board revised the methodology for determining jurisdictions with systemically important financial sectors and its application led to an increase in the number of systemically important jurisdictions to 29. 'Financial Sector Assessment Programme', n (43).

47 FSB, 'Implementation and Effects of the G2o Financial Regulatory Reforms: Fourth Annual Report' (28 November 2018) <www.fsb.org/2018/11/implementation-and-effects-of-theg2o-financial-regulatory-reforms-fourth-annual-report/> accessed 21 October 2021.

48 'IMF Lending' (2021) <www.imf.org/en/About/Factsheets/IMF-Lending> accessed 21 October 2021.

49 For a detailed description on the Fund's conditional financial assistance see Lastra, International Financial and Monetary Law (n 7) 463-482. 
The Fund's recommendations in these aspects are contained in technical assistance reports at the request of the members. ${ }^{50}$

\subsection{International Standard-Setting and Soft Law}

As stated above, the normative aspect of the IFA is based on a system of IFSs that is mostly based on soft-law arrangements. The so-called 'soft law' are rules or standards characterised as informal, voluntary and non-enforceable. Soft law usually emerges to fill regulatory 'gaps' but it cannot replace the named 'hard law' or formal law. Hard law, as opposed to soft law, is characterised as being formal, externally imposed and enforceable. ${ }^{51}$ In an interesting and detailed article written by Shaffer and Pollack the authors explored how hard and soft law interact under different conditions and observed that existing literature on the topic can be sorted by the three main theories: legal positivist, rationalist and constructivist. ${ }^{52}$ They remarked that:

Legal positivists tend to favor hard law and view hard and soft law in binary terms. For them, hard law refers to legal obligations of a formally binding nature, while soft law refers to those that are not formally binding but may nonetheless lead to binding hard law. Rationalists, in contrast, contend that hard and soft law have distinct attributes that states choose for different contexts. They also find that hard and soft law, in light of these different attributes, can build upon each other. Constructivists maintain that state interests are formed through socialization processes of interstate interaction which hard and soft law can facilitate. Constructivists often favor soft-law instruments for their capacity to generate shared norms and a sense of common purpose and identity, without the constraints raised by concerns over potential litigation. ${ }^{53}$

50 'IMF Capacity Development' (2021) <www.imf.org/en/About/Factsheets/imf-capacitydevelopment $>$ accessed 21 October 2021.

$5^{1} \quad$ Eilis Ferran and Kern Alexander, 'Can Soft Law Bodies be Effective? The Special Case of the European Systemic Risk Board' (2010) 35(6) European Law Review 751; Chris Brummer, 'Why Soft Law Dominates International Finance - and not Trade' in Thomas Cottier and others (eds), International Law in Financial Regulation and Monetary Affairs (Oup 2010); Chris Bummer, Soft Law and the Global Financial System - Rule Making in the 21st Century (CUP 2011).

52 Gregory C Shaffer and Mark A Pollack, 'Hard vs. Soft Law: Alternatives, Complements, and Antagonists in International Governance' (2010) 94 Minn L Rev 706. ibid 707 . 
According to this categorisation it can be argued that the emerging principle of Common Concern favours a rationalist approach to the interaction between hard law and soft law, with the view to complement each other in the development of international law. The authors also highlight that the rationalist scholars acknowledge the main advantages and disadvantages of the use of hard and soft law as alternatives from an institutional view point. ${ }^{54}$ Briefly, they argued that hard-law instruments make state commitments more credible because they can have direct legal effects in national jurisdictions or they can require domestic legal action. Also, hard law instruments allow states to monitor and enforce their commitments, including through the use of dispute-settlement bodies such as courts. However, rationalists also recognise that hard law agreements involve significant costs and are less flexible to adapt to changing circumstances. Moreover, they noted that hard law formal commitments may restrict the behaviour of states and infringe on their sovereignty in sensitive areas such as money and finance. In respect of soft law instruments, rationalists consider that they are easier and less costly to negotiate and impose less sovereignty costs on states in sensitive areas. Also, these instruments provide greater flexibility and allow states to engage in enhanced cooperation without worrying about enforcement.

Notwithstanding the above-mentioned advantages of the institutional use of soft law instruments, it is still a contended subject for legal and international relations scholars. Consequently, in this specific case study there are still some major challenges concerning the institutional legitimacy of the entities involved in the process of IFS s and the limits of the soft-law approach in IFS s that remain unsolved. ${ }^{55}$ As remarked by Brummer, 'Yet perhaps the most difficult challenge derives from the fact that the production of international financial law departs from the classical model of public diplomacy embodied by formal "international organizations" .56 That is, international financial standards are issued mostly by informal international groupings created under informal by-laws, agreements or declarations. These arrangements provide efficiency and flexibility but they are unable to create international commitments or formal legal obligations in the traditional sense unless they are incorporated into domestic legislation and turned into legally binding rules. The implementation of the IFSs are actively promoted both by market incentives and official incentives (e.g. peer pressure, ROSC s, FSAP s). ${ }^{57}$

54 ibid 717.

55 Mario Giovanoli, 'The International Monetary and Financial Architecture' (n 27) 45.

56 Brummer, Soft Law and the Global Financial System (n 20) 63.

57 Mario Giovanoli, 'The International Monetary and Financial Architecture' (n 27) 65 . 
Brummer classifies these soft-law instruments in three categories: best practices, regulatory reports and observations, information sharing and enforcement cooperation agreements. ${ }^{58} \mathrm{He}$ considers that best practices usually acquire the form of 'core principles' or 'codes of conduct' in order to provide the minimum standards to be achieved on specific financial issues considering the diversity of markets and regulatory authorities involved. Main examples of soft-law instruments in this category are the core principles issued by the International Organisation of Securities Commissions (IOSCO) on securities regulation and the вСвS for banking. On regulatory reports and observations Brummer points out that they are used by local and global regulators to collect data and produce assessments that may influence the course of policy making in financial and monetary law. Key examples are the reports produced by international organisations and relevant global experts during the GFC, such as the IMF report issued in February 2009 concerning financial sector regulation and supervision and central bank liquidity management titled 'Lessons of the Financial Crisis for Future Regulation of Financial Institutions and Markets and for Liquidity Management'59 and the so-called 'Rapport Camdessus' 60 issued in February 2011 by a group of worldwide leading economists focused on international monetary stability. On information sharing agreements Brummer highlights that they mostly take the form of memoranda of understanding to promote better international coordination among domestic regulators to improve the surveillance of globally active domestic institutions. Concerning enforcement cooperation agreements he notes that they are also usually with the form of memoranda of understanding to address the terms under which countries assist each other while enforcing domestic obligations overseas. Main examples of this category of soft-law instruments are linked to banking and securities regulatory issues.

Giovanoli provides an analysis of the issues concerning the legitimacy or representativity of the IFA institutions on a case by case basis. ${ }^{61} \mathrm{He}$ pointed out that while both the IMF and the World Bank have almost universal

58 Brummer, Soft Law and the Global Financial System (n 20) 121.

59 IMF, 'Lessons of the Financial Crisis for Future Regulation of Financial Institutions and Markets and for Liquidity Management' (4 February 2009) <www.imf.org/en/ Publications/Policy-Papers/Issues/2016/12/31/Lessons-of-the-Financial-Crisis-for-FutureRegulation-of-Financial-Institutions-and-Markets-PP4316> accessed 21 October 2021.

6o Palais-Royal Initiative, 'Reform of the International Monetary System: A Cooperative Approach for the Twenty First Century' (8 February 2011) <http://global-currencies.org/ $\mathrm{smi} / \mathrm{gb} /$ telechar/news/Rapport_Camdessus-integral.pdf $>$ accessed 21 October 2021 (the 'Rapport Camdessus').

61 ibid 55 . 
membership, it is not in the case of the BIS, which has a membership of 45 members from 28 jurisdictions (consisting of central banks and authorities with formal responsibility for the supervision of banking business), the G2O, which comprises of 19 individual countries plus the European Union, and the FSB, which consists of 68 member institutions from 25 jurisdictions (comprising ministries of finance, central banks, and supervisory and regulatory authorities) and also 10 international organisations and standard-setting bodies and 6 regional consultative groups.

As a result, Giovanoli considers that there is no legitimacy problem for the BIS because its role in the standard-setting process is limited to initiating, hosting and financing some of the standard-setting bodies such as вСвS and the FSB and is not involved in the process itself. The issue is more complex for the $\mathrm{G} 2 \mathrm{O}$ because of its informal nature as a political steering group without a legal mandate. However, Giovanoli invokes the argument that the G2o represents around 85 percent of the world gross domestic product and involves over two-thirds of the global population which gives it a powerful informal role in the conduct of the IFA. Concerning the FSB, the membership was expanded in 2009 and as a result it includes more emerging economies. Yet, it can be argued that for both the G2O and the FSB there is still an issue of selective and restrictive membership.

The decision-making in the standard-setting process of IFSs is usually based on general consensus which has been highly successful because it lends credibility to the decision and ensures acceptance of the standards. ${ }^{62}$ Notwithstanding that, Giovanoli remarks that this successful decision-making approach has also raised an issue of transparency because the arrival at such consensus outcome involves a degree of confidentiality that prevents an open debate. That said, he also points out that this issue has been mitigated with the implementation of wide consultation process. ${ }^{63}$

To sum up, the soft law instruments in the form of IFS s have been a key success in the development of a more robust and resilient international order in monetary and financial law. However, the above-mentioned shortcomings on legitimacy and transparency surrounding the standard-setting process are not fully addressed yet. In concordance, Giovanoli affirms that:

62 The decision-making process, both at the IMF and the World Bank, follows the principle of weighted voting power. That is, an objective system of quotas based on the economic power of each member. ibid 55 . ibid 58 . 
without minimising the contribution of IFS s to international financial stability, it is important to recognise their limits: they are not a talisman warding off international financial crises and are certainly not a substitute for the prudent behaviour of all stakeholders, including not only financial institutions and their regulators, but also monetary authorities and politicians, acting with a view to preventing excessive credits or overindebtedness leading to dangerous bubbles. ${ }^{64}$

\section{Bottom-up Approach - Central Banking Cooperation}

This section studies cross-border cooperation among countries from a bottomup approach with a special emphasis on monetary policy coordination and cooperation among central banks. Cross-border central banking cooperation is not a new phenomenon and it relates back to the late nineteenth and early twentieth centuries. ${ }^{65}$ Hence, this section starts by examining the evolution of central banking cooperation through history. Then it continues with a description of the main examples of effective central bank involvement in international coordination since the collapse of the Bretton Woods system and ends with an analysis of the responses provided by central banks during and after the GFC up to date.

\subsection{The Evolution of Central Banking Cooperation}

The evolution of this type of international cooperation has been intrinsically linked with the development of the international monetary and financial systems and the recurrent economic and financial crises throughout history that have acted as catalysts for change. Also, central banking cooperation has been strongly influenced by the evolving notion or conception of monetary stability and financial stability both domestically and globally. That is, monetary stability and financial stability are not only considered as key domestic public goods but also as desired global public goods as discussed in chapter 3 of this book.

In this regard, Borio and Toniolo remarked in 2006 that:

64 Mario Giovanoli, 'The International Monetary and Financial Architecture' (n 11$) 70$.

65 For an excellent description on the history of monetary cooperation, see Lastra, International Financial and Monetary Law (n 7) ch 12. Also see Douglas W Arner, Michael A Panton and Paul Lejot, 'Central Banks and Central Bank Cooperation in the Global Financial System' (2010) 23(1) Pacific McGeorge Global Business \& Development Law Journal 1,31 . 
Central bank cooperation through history has ultimately been directed to ensuring monetary and financial stability. However, the conception of these objectives, the relationship between the two, the balance in their pursuit, and the strategies followed have evolved over time, reflecting changes in the monetary and financial environment as well as in the political and intellectual climate. Accordingly, depending on the circumstances and the intellectual perspective of the time, we think of monetary stability as covering either stability in an aggregate price level (index) or in the relative price of two units of account, i.e. the exchange rate between national currencies or between a given currency and gold. We think of financial stability, narrowly defined, as being impaired whenever widespread defaults threaten to take place, due to either a banking or a sovereign debt crisis. ${ }^{66}$

Broadly speaking, central banking cooperation can be divided into three historical periods: the 'Gold Standard Period', the 'Bretton Woods Period' and the 'Post-Bretton Woods Period'.67 Each of these periods have experienced different levels of intensity of cross-border banking cooperation. According to Caruana, former general manager of the BIs, in a speech given in July 2012 the main factors that have determined and continue to determine the level of cooperation in each of these periods are 'the challenges presented by the evolution of the international monetary and financial environment, changes in institutional frameworks and advances in economic thought' ${ }^{\prime} 8$

66 Claudio Borio and Gianni Toniolo, 'One hundred and thirty years of central bank cooperation: a BIS perspective' (2006) BIS Working Papers No 197 <www.bis.org/publ/work197. htm> 27 March 2019, 2.

67 These periods coincide with the historical evolution of the International Monetary System as explained in chapter 1 of this book: starting with the period of the Gold Standard (18191914) and the Gold Exchange Standard (1925-31), continued by the Bretton Woods System (1944-73) and closing with the ongoing Post-Bretton Woods period (1973-present). For a more detailed explanation of these historical periods see Annex I to chapter 1 in this book.

68 Jaime Caruana, 'Central bank cooperation: reflections on the experience of the last eight decades' (CEMLA's 6oth Anniversary Commemorative Conference on 'Central bank cooperation at the beginning of the 21st century', 20 July 2012) <www.bis.org/speeches/ sp120724.htm> accessed 21 October 2021. Borio and Toniolo added the following factors on top of the factors highlighted by Caruana: (i) the overall conditions in international relations; (ii) the prestige enjoyed by central banks with the public at large, which also affects their institutional relationship with the political authorities (i.e. the allocation of tasks in monetary policymaking, including provisions for central bank independence); and (iii) the technical nature of the problems requiring cooperation.

Borio and Toniolo, 'One hundred and thirty years of central bank cooperation' (n 66) 3 . 
With these factors in mind, Caruana provides in his 2012 speech a clear detail of the level of international cooperation experienced during the abovementioned three periods that can be summarised as follows:

'Gold Standard Period' (1819 - 1931): This period includes both the Classic Gold Standard (1819-1914) and the Gold Exchange Standard (1925-31). Under the Classic Gold Standard, gold convertibility was believed to achieve both stable prices (monetary stability) and financial stability. Hence, central bank cooperation was limited to the maintenance of gold convertibility mostly on a bilateral basis and through emergency liquidity lending to central banks with low level of gold reserves. The First World War marked the abandonment of the Classic Gold Standard and the imposition of exchange controls. International efforts to restore the standard were made in the interwar period with an increase in central bank cooperation that led to the creation of the BIS in 1930 as an institutionalised vehicle for multilateral cooperation. ${ }^{69}$ However, with the onset of the Great Depression in the 1930's central bank cooperation reduced and the BIs acted as a forum for research and exchange of information among central banks.

'Bretton Woods Period' (1944 - 1973): This second period was characterised by the establishment of fixed but adjustable exchange rate regimes, with gold initially acting only as a soft limit on the system, but which de facto evolved to the dollar standard or 'par value' regime (each currency had a par value with gold or with the US gold dollar standard). A newly established international organisation, the IMF, was entrusted with the management of the exchange rates. Consequently, during this period international central banking cooperation was focused on re-establishing the conditions for current account convertibility and sustaining fixed exchange rates through the provision of emergency liquidity lending and the so-called 'gold pool. ${ }^{70}$

69 Wartime reparations and debts provided the rationale for the creation of the BIs, as remarked by Borio and Toniolo: The main driving force behind the creation of an 'international bank', as part of a treaty on reparations, was the so-called 'commercialisation' of the reparation payments, whereby part of the German debt would be issued in the form of long-term bonds to be subscribed by international private banks and financial houses. (...) Given that obligations of sovereign states are notoriously difficult to enforce, the creation of an international organisation such as the BIS was seen as potentially useful in improving the chances of future payments enforcement.

Borio and Toniolo, 'One hundred and thirty years of central bank cooperation' (n 66) 9 .

70 ibid 3. According to Borio and Toniolo the 196o's saw a peak in central bank cooperation. In particular, decisions on the gold pool, the sterling group agreements, the IMF General Agreement to Borrow (GAB) and the G-10 multilateral surveillance were held under the auspices of the BIs. ibid 14 . 
'Post-Bretton Woods Period' (1973 onwards): With the collapse of the Bretton Woods system at the beginning of the 1970's, international central banking cooperation on monetary affairs became limited. Floating exchange rate regimes emerged and domestic price stability turned out to be the main task of central banks. Hence, global cooperation for monetary stability considerations was restricted and domestic affairs prevailed over international solutions. ${ }^{71} \mathrm{On}$ the contrary during this same period, the scope for global cooperation in financial affairs gained place. Financial openness with quick expansion of international banking and international capital mobility gave rise to more recurrent banking crises that prompted an increase in central banking cooperation in the pursuit of international financial stability.

The collapse of the Herstatt Bank in Germany and the Franklin National Bank in the United States of America (US) at the beginning of 1974 gave momentum to the creation of the всвS and other committees hosted by the BIS. As explained in the previous section of this chapter, these committees were and are still aimed at developing common standards and policies in the field of international monetary and financial cooperation. Consequently, according to Borio and Tonniolo, the evolution of the elements of cooperation both in monetary and financial matters was based mainly on standards and codes through soft law provisions and arrangements, thus shaping the so-called new 'international financial architecture' as detailed in the previous section of this chapter. ${ }^{72}$

\subsection{Diplomacy and Coordination}

As stated before, central bank cooperation has evolved over time and adapted to the new economic and financial landscapes. Simmons remarks that 'central bank cooperation has adapted remarkably well to the demands of the times. (...) Cooperation among them has been shaped by the economic conditions they have encountered, the theoretical lenses through which they view the world, and even the political context in which they operate. ${ }^{73}$ These central bank interactions through history have been analysed from different angles by legal, economic and political scientist scholars and an interesting classification

71 Europe marked the exception to the general trend towards limited global cooperation on monetary policy affairs during this period, because it was then when it started to design the regional monetary union with the so-called currency snake and the European monetary system. Caruana, 'Central Bank Cooperation' (n 68) 2.

72 Borio and Toniolo, 'One hundred and thirty years of central bank cooperation' (n 66) 16.

73 Beth A Simmons, 'The future of central bank cooperation' (2006) BIs Working Papers No $200<$ www.bis.org/publ/work2oo.htm $>$ accessed 21 October 2021. 
for these interactions was made by Kahn and Meade in 2018. ${ }^{74}$ They divide central bank interactions into two main categories named 'diplomacy' and 'coordination'. Diplomacy refers to the relationship-building initiatives among central banks including all forms of public and non-public information exchange usually taking place in the context of international forums aiming to create knowledge and professional relationships and to enhance trust. Coordination encompasses joint actions performed by central banks such as, standard or rule setting, foreign exchange market intervention and liquidity provision. ${ }^{75}$ Kahn and Meade relate both categories by stating that, 'Although coordination does not necessarily occur only in times of crisis, relationships built through diplomacy lay the ground work for coordination when a crisis occurs. ${ }^{76}$

Under diplomacy Kahn and Meade highlight the role of main international forums and organisations in which central banks participate. As detailed in the previous section of this chapter, these interactions among central banks are mainly held at diverse working groups and meetings within IMF, BIS, FSB and G2O. As to how central banks move from diplomacy to effective coordination the authors discuss three relevant examples: the Plaza Accord of 1985, the response to the Asian financial crisis of 1997-98 and the more recent responses to the GFC. ${ }^{77}$

I concur with Kahn and Meade that these are the three leading examples of central bank involvement in international coordination since the collapse of the Bretton Woods system. I will describe briefly the first two examples and in the following section examine in detail the most recent episode, the GFC.

The Plaza Accord of 1985: The Plaza Accord of 1985 is the result of a meeting held at the Plaza Hotel in New York on 22 September 1985 among the Group of Five (G-5) which comprised of the largest industrialised countries at that time (France, West Germany, Japan, the United States and the United Kingdom). In this accord the countries agreed to act jointly in order to bring down the value of the US dollar through coordinated currency markets intervention. ${ }^{78}$ The text of the Plaza Accord signed by the G-5 countries states that:

74 Robert B Kahn and Ellen E Meade, 'International aspects of central banking: diplomacy and coordination' in Peter Conti-Brown and Rosa Maria Lastra (eds), Research Handbook on Central Banking (EE 2018).

75 ibid 334 .

76 ibid 335 .

77 ibid 335-357.

78 Jeffrey Frankel explains the reasons leading to the appreciation of the US dollar in the early 1980's: 'A combination of tight monetary policy associated with Federal Reserve Chairman Paul Volcker during 1980-82 and expansionary fiscal policy associated with President Ronald Reagan during 1981-84 pushed up long-term interest rates, which in turn attracted a capital inflow and appreciated the currency'. Jeffrey Frankel, 'The Plaza 
The Ministers and Governors agreed that exchange rates should play a role in adjusting external imbalances. In order to do this, exchange rates should better reflect fundamental economic conditions than has been the case. They believe that agreed policy actions must be implemented and reinforced to improve the fundamentals further, and that in view of the present and prospective changes in fundamentals, some further orderly appreciation of the main non-dollar currencies against the dollar is desirable. They stand ready to cooperate more closely to encourage this when to do so would be helpful. ${ }^{79}$

The Plaza Accord is widely seen as successful in terms of both international diplomacy and international coordination. The value of the US dollar fell abruptly after the announcement of the agreement and in the period of two years with concerted intervention ended at 40 per cent of its previous value. Also, as a consequence of this successful cooperation among the G-5 countries, the group was expanded in 1986 to include Italy and Canada. The new Group of 7 (G-7) continues to meet annually since its creation and also includes the European Union as a non-enumerated member. Central banks played without doubt a key role through their involvement both in the debates and studies about foreign-exchange intervention prior to the signing of the Plaza Accord and also with the subsequent execution of the intervention operations in the exchange market. ${ }^{80}$

Despite the success of the Plaza Accord of 1985 and other similar agreements, such as the subsequent Louvre Accord of $1987,{ }^{81}$ they are described by Proctor as agreements of short-term validity and of limited legal force since, 'international law knows of no general obligation to maintain exchange rates at particular levels, and that statements of this kind - whatever their political value- have limited legal force in the monetary sphere. ${ }^{82}$

Accord, 30 Years Later' (2015) NBER Working Paper 21813 <www.nber.org/papers/w21813> accessed 21 October 2021.

79 Group of 5, 'Announcement the Ministers of Finance and Central Bank Governors of France, Germany, Japan, the United Kingdom, and the United States (Plaza Accord)' (22 September 1985) < www.g8.utoronto.ca/finance/fm850922.htm > accessed 21 October 2021.

8o Kahn and Meade, 'International Aspects of Central Banking' (n 74) 347.

81 In February 1987, the Group of 6 (G-6) finance ministers (consisting of G-5 and Canada) met at Paris, France and agreed that the value of the US dollar had fallen far enough, that future market intervention should occur only when required to ensure exchange rate stability and that they would try to prevent it from falling further. Group of 6, 'Statement of the G6 Finance Ministers and Central Bank Governors (Louvre Accord)' (22 February 1987) <www.g8.utoronto.ca/finance/fm870222.htm> accessed 21 October 2021. Charles Proctor, Mann on the Legal Aspect of Money (7th edn, OUP 2012) 888. 
The response to the Asian financial crisis of 1997-98: During the 199o's increasing globalisation facilitated the growth of international financial markets with emerging economies taking the lead. However, international diplomacy and coordination in international finance was still dominated by developed economies, mostly accomplished at the G-7 meetings and with the IMF as the leading international organisation for monetary and financial issues. Hence, when the Asian financial crisis erupted in 1997 (when the Thai government decided to stop pegging its currency against the US dollar), the capacity of global policymakers and institutions was challenged. ${ }^{83}$

The Asian financial crisis arose as a combination of macroeconomic factors (most of the Asian region had at that time fixed or semi-fixed exchange rates) and microeconomic problems (associated with balance sheet mismatches). ${ }^{84}$ Capital outflows intensified in the region by the end of 1996 and with the end of the peg of the Thai currency (the baht) to the US dollar in 1997, countries such as Indonesia and Philippines decided to request for financial assistance from the IMF. These multilateral funds were also complemented with central banks funds. ${ }^{85}$

The increasing global growth of regionalism with the creation of the European Monetary Union and the launch of the Eurozone in 1999 influenced the Asian countries to develop regional financial forums in order to protect and promote their regional interests. Accordingly, the regional responses to the crisis where notable, mostly catalysed through the work of the Association of Southeast Asian Nations Plus Three (ASEAN + 3) and the Executive Meeting of

83 For a comprehensive analysis of the Asian financial crisis of the 199o's see Jee-young Jung, 'Regional financial cooperation in Asia: challenges and path to development' (2008) BIS Papers No $42<$ https://www.bis.org/author/jee-young_jung.htm> accessed 21 October 2021. See also Takatoshi Kato, 'Can the East Asian Miracle Persist?' (Princeton University's Woodrow Wilson School and East Asian Studies Department, 2 December 2004) <www .imf.org/en/News/Articles/2015/o9/28/04/53/sp12O2O4> accessed 21 October 2021; Edwin M Truman, 'Asian and European Financial Crises Compared' (2013) Peterson Institute for International Economics Working Paper No 13-9 <https://papers.ssrn.com/sol3/papers .cfm?abstract_id=2344421 $>$ accessed 21 October 2021.

84 Truman explains that: The Asian countries had fixed or semi-fixed exchange rates, which was a source of problems ex ante because the exchange rate regimes encouraged currency mismatches and the buildup of excessive foreign debts by the private sector, including financial institutions. Exchange-rate regimes became an additional source of problems when the pegs broke or were broken, and the sequential collapse of pegs contributed to contagion in the region. The collapse of the pegs magnified recessions in the short run, via balance sheet effects.

Truman, 'Asian and European Financial Crises Compared' (n 83) 9-10. Kahn and Meade, 'International Aspects of Central Banking' (n 74) 349. 
East Asia-Pacific Central Banks (EMEAP). ${ }^{86}$ These regional financial cooperative efforts resulted in the establishment of regional liquidity support arrangements through the Chiang Mai Initiative (CMI), the creation of the Asian Bond Fund $(\mathrm{ABF})$ and the development of the Asian Bond Market Initiative (ABMI). ${ }^{87}$ In this context it can be stated that the role of the central banks was crucial both in terms of diplomacy and cooperation, although they were bolstered by the political support of their governments and the decisive support of the IMF.

Notwithstanding the remarkable regional responses to the Asian financial crisis, they were not sufficient because the crisis escalated and spilled over quickly within the region and beyond. As a consequence, global policymakers recognised that the voices of major emerging economies should be heard and as a result the G2o group of central bank governors and finance ministers was created. According to Kahn and Meade the Asian financial crisis of the 199o's 'created a new appreciation that shocks affecting one country could spill over quickly to others in the region. Increased dependence on foreign capital and bank loans, as well as underdeveloped domestic financial markets, were seen as creating unique regional vulnerabilities from global swings in capital flows' 88

\subsection{Responses to the $\mathrm{GFC}$ and Its Aftermath}

There is much written about the global financial crisis (the GFC) that erupted in the fall of 2007, bringing about the loss of confidence of investors in the US subprime mortgage market that developed quickly into a global liquidity crisis with the collapse of Lehman Brothers in September 2008 as the inflection point. ${ }^{89}$ For the purposes of this chapter, this section examines the responses provided by central banks during the crisis and in its aftermath.

In terms of the categorisation between diplomacy and cooperation, Kahn and Meade consider that the first set of responses provided by central banks to the GFC fall under the category of diplomacy. That is, there were plenty of communications and consultations among central banks about

86 During the crisis Japan proposed to create an Asian Monetary Fund. However, this initiative was rejected on the basis that it would have produced a large freestanding source of external financing unconnected and competing with the IMF and the global policy standards. Truman, 'Asian and European Financial Crises Compared' (n 83) 40.

87 Jung, 'Regional Financial Cooperation in Asia' (n 83). Jung provides an extensive assessment of the Asian regional forums and initiatives undertaken during and after the 199o's Asian financial crisis.

88 Kahn and Meade, 'International Aspects of Central Banking' (n 74) 353.

89 Lastra and Wood, 'The Crisis of 2007-2009: Nature, Causes, and Reactions' (n 14). 
the ongoing crisis with sharing of information and market analysis, but the policy responses were not coordinated. However, with the Lehman Brothers collapse central banks moved quickly from the category of diplomacy to the category of cooperation. That is to say, central banks cooperated with specific actions aimed to alleviate some of the effects of the crisis and also to send a joint signal to the financial markets on the direction that their policies would take.

According to Heath, 'Spontaneous coordination may occur in a global crisis because countries may face similar circumstances that overwhelm other individual country conditions, and so many nations' interests align in seeking action. ${ }^{90}$ Some examples of cooperation during the crisis, or as a response to the crisis, were the synchronised reduction by six central banks of their respective interest rate policies by $25^{-5}$ o basis points after the collapse of Lehman Brothers, the almost simultaneous start of monetary easing of the major central banks in October $2008^{91}$ and also the establishment of swap lines among the US Fed and various central banks of economies considered to be major and advanced. ${ }^{92}$ As highlighted by Kahn and Meade:

The success of the swap lines in mitigating funding pressures and reducing interbank borrowing rates is considered one of the major successes from central bank coordination during the crisis. In addition to easing funding shortages, these swaps also contributed to an alleviation of market fears and sent a strong signal that central banks were prepared to move outside their comfort zone to address financial stress. ${ }^{93}$

90 Daniel Heath, 'International Coordination of Macroprudential and Monetary Policy' (2013-2014) 45 Georgetown Journal of International Law 1093.

91 ibid. The coordinated reduction of the interest rate was taken on 8 October 2008 among the Bank of Canada, the Bank of England, the есв, the Fed, the Sveriges Riksbank, and the Swiss National Bank. As remarked by James, 'This was the first time that the Fed had ever coordinated a simultaneously announced rate reduction with other central banks'. Harold James, 'International Cooperation and Central Banks' in Youssef Cassis, Catherine Schenk, and Richard Grossman (eds), The Oxford Handbook of Banking and Financial History (OuP 2016) 22.

92 The Fed started liquidity lines with the Есв and the Swiss National Bank in December 2007, with twelve more central banks in September to October 2008. Rakesh Mohan and Muneesh Kapur, 'Monetary Policy Coordination and the Role of Central Banks' (2014) IM F Working Paper 14/70 <www.imf.org/external/pubs/ft/wp/2014/wp1470.pdf> accessed 21 October 2021.

Kahn and Meade, 'International Aspects of Central Banking' (n 74) 357. 
Notwithstanding the above-mentioned examples, most of the solutions adopted to manage the GFC were nation-oriented and uncoordinated. As remarked in a discussion paper by the Bank of England, "The landscape for international monetary policy co-operation has not changed in any fundamental way since the crisis: with the exception of the co-ordinated monetary easing at the onset of the crisis, conventional monetary policy is still being set by individual central banks without co-ordination. ${ }^{94}$ For example, the setting of key interest rates is one of the main instruments (together with open market operations and reserve requirements) in monetary policy used by central banks in search of monetary stability. As a response to the crisis, central banks resorted to this instrument but used it differently. As remarked by Zimmermann:

The Fed reacted with a series of interest rate cuts aimed at saving employment while the Есв kept interest rates unchanged for much longer in order not to endanger price stability. This illustrates that the current lack of harmonization in the way interest rates policies are being conducted by central banks may lead to major differences in how similar economic problems are tackled by different countries. ${ }^{95}$

As a reaction to this situation, the IMF Staff Team prepared a discussion note paper about the form monetary policy should have in the aftermath of the GFC. In this discussion paper they argued that in crisis times, 'the potential gains from cooperation are significant. Cooperation reduces the risk of tail events with large international feedback effects, and in those circumstances, central banks have been willing to cooperate'. While in regular times, 'there is insufficient clarity on the size of the welfare gains from monetary policy cooperation: ${ }^{96}$ Moreover, the discussion note remarks that even though the welfare gains were clear during normal times there are several obstacles to cooperation. It listed the obstacles that range from the different economic situations

94 Bank of England, 'One Bank Research Agenda Discussion Paper' (February 2015) <https:// www.bankofengland.co.uk/-/media/boe/files/research/one-bank-research-agenda-

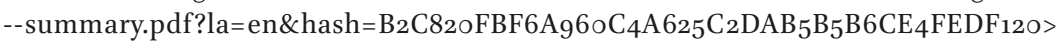
accessed 21 October 2021.

95 Claus D Zimmermann, 'Global Benchmark Interest Rates' in Cottier and others (eds), The Rule of Law (n 18).

96 Tamim Bayoumi and others, 'Monetary Policy in the New Normal' (ImF Staff Discussion Note, April 2014) < www.imf.org/external/pubs/ft/sdn/2014/sdn1403.pdf > accessed 21 October 2021. 
across countries to the lack of harmonised domestic objectives for the pursuit of monetary stability.

On the obstacles to international monetary policy cooperation, Ostry and Ghosh pointed out that 'the most compelling reasons are asymmetries in country size; disagreement about the economic situation and cross-border transmission effects of policies; and often policymakers' failure to recognise that they face important trade-offs across various objectives'. To address these concerns they proposed on one hand that 'a neutral assessor may play a useful role in helping to bridge the divergent views of national policymakers' and on the other hand 'to buttress international coordination and to provide safeguards when coordination proves impossible to achieve, by implementing two guideposts to limit negative spillovers through the current account and the capital account, respectively'. ${ }^{97}$

Consequently, it is very difficult to foresee under different circumstances what shape international cooperation for the pursuit of monetary stability will take. Kahn and Meade consider that in the GFC aftermath central banks will remain as key actors for global stability and, hence, central bank diplomacy should be maintained and improved. ${ }^{98}$ In this regard Coeuré reflects that both formal and informal international institutions and fora must keep a leading role in the further development of central bank diplomacy for three reasons:

First, they achieve a better understanding and a common assessment of the global spillovers from domestic policy actions and the potential policy trade-offs. Second, even if the scope for coordination is limited in good times, they make coordination possible in bad times. And third, they prompt work at regulatory bodies such as the Basel Committee for Banking Supervision, the International Organization of Securities Commission or the Committee on Payments and Settlement Systems, to establish the standards and infrastructures and create a level playing field, which are necessary for global markets to function in a smooth and safe way. ${ }^{99}$

97 Jonathan D Ostry and Atish R Ghosh, 'Obstacles to International Policy Coordination, and How to Overcome Them' (IM S Staff Discussion Note, December 2013) < www.imf.org/ external/pubs/ft/sdn/2013/sdn1311.pdf > accessed 21 October 2021.

98 Kahn and Meade, 'International Aspects of Central Banking' (n 74) 36o.

99 Benoît Coeuré, 'The Internationalisation of Monetary Policy' (2016) 67 Journal of International Money and Finance 11. 


\section{Common Concern as a Guide to Enhanced Cooperation in Monetary Affairs}

From all the considerations expressed above, it can be argued that the duty to cooperate in monetary affairs relies mostly on voluntary cooperation. It is here that the potential principle of Common Concern can assist with the new 'obligation to act'. ${ }^{100}$ If recognised as a principle of international law, Common Concern will entail the lawful implementation of instruments and incentives supporting international compliance and securing that a recognised Common Concern - such as international monetary stability- is dealt with in priority in domestic and international processes. Hence, it is the responsibility of cooperation emanating from the recognition of international monetary stability as a Common Concern that lays the ground for such new duty at the different levels of governance.

The application of the doctrine of Common Concern to the transboundary public good of monetary stability, suggests different avenues to help solve the cooperation failures. This book, considers the following three areas as examples of enhanced cooperation assisted by the normative claims proposed by Common Concern: Im F surveillance, Global Financial Safety Net (GFSN) and government networks.

\section{1}

IMF Mandatory Based Surveillance

The principle of Common Concern recommends that a progressive move from soft law to hard law in international monetary affairs (top-down approach), might help the national monetary authorities to honor their international legal commitments and engage in further cross-border cooperation. For example, moving from a voluntary to a mandatory based surveillance under the IMF's consultations (made through FSAP and ROSCs). Hence, all policy recommendations made in the context of IMF surveillance could become of mandatory nature.

Therefore, based on the normative claims of the emerging doctrine of Common Concern doctrine, a more effective and impactful IMF surveillance could be promoted. Mark Carney, former governor of the Bank of England, has argued in this regards that '... transparent, evidence-based discussions convened by the IMF can both discipline policy and avoid potentially antagonistic misunderstandings that could lead to de-stabilising tit-for-tat retaliations'. Consequently, the Fund could play a fundamental role in informing

100 Cottier, 'The Principle of Common Concern of Humankind' (n 1 ) 73. 
both domestic and cross-border policies based on its bilateral surveillance performed to individual countries and its multilateral surveillance of the global economy.

\subsection{Improved GFSN}

Another possible option to induce cooperation from a top-down approach is to reinforce the GFSN. ${ }^{101}$ As described elsewhere in this book, excessive reserve assets accumulation and reliance on few reserve currencies together with the proliferation of regional financing agreements (RFAs) is not only very costly, but also causes potential systemic costs and coordination problems that can affect the stability of the IMs. Consequently, a principle of Common Concern with an enhanced duty to cooperate could promote a stronger and more reliable GFSN. In this regard, Carney remarks that 'Collective action should improve the adequacy of the global financial safety net (GFSN) to reduce the need for EMEs to accumulate reserves of safe assets as insurance against less sustainable capital flows'.. ${ }^{102}$

The report published in October 2018 by the G2o Eminent Persons Group on Global Financial Governance (EPG) offers a range of proposals to improve the GFSN with enhanced cooperation from a top-down approach:103

First, we must ensure an adequately-resourced global layer in the IMF through timely conclusion of quota reviews.

Second, the IMF must work with RFAs to enable consistent actions during a crisis so as to achieve the necessary scale and global impact. A properly designed and predictable GFSN can avoid moral hazard, minimize contagion between countries, and promote openness and growth.

101 On the topic of G FSN, chapter 1 of this book defines 'reserve assets' as a key element of the IMS and chapter 5 explains that the management of reserve assets is part of the foreign exchange policy of a country. Moreover, chapter 6 of this book analyses the accumulation of reserve assets as a unilateral measure of precautionary nature and contains a note on the proliferation of regional financing agreements as an alternative to manage volatility caused by monetary policy spillovers.

102 Mark Carney, 'Speech' (The Growing Challenges for Monetary Policy in the current International Monetary and Financial System, London, 23 August 2019) $12<$ www.bis.org/ review/r19o827b.htm > accessed 21 October 2021.

103 Eminent Persons Group on Global Financial Governance, 'Making the Global Financial System Work for All' (October 2018) <www.globalfinancialgovernance.org/assets/pdf/ G2oEPG-Full\%2oReport.pdf> accessed 21 October 2021. 
Third, it is important to put in place a standing global liquidity facility, drawing on IMF permanent resources, to strengthen countries' ability to withstand global liquidity shocks and avoid deeper crises. A reliable liquidity facility will also help them avoid building up excessive reserves as the price for being open to capital flows, and hence avoid hampering growth. The facility should be designed for countries with sound policies, and to minimize 'IMF stigma' when they draw on it.

These proposals to enhance the GFSN presented by the G2O EPG could only be viable if the members of the international community and specially the IMF member states honor their international legal commitments and engage in further cross-border cooperation.

\subsection{Harness the Commitments Assumed at the Government Networks}

A proposal to promote enhanced cooperation from a bottom-up approach can be found in the very influential work on 'government networks' wrote by Anne-Marie Slaughter. In this work Slaughter explains that global governance can occur through government networks that connect domestic government officials to address international problems. ${ }^{104}$ She suggests that government networks are the optimal tool of international cooperation to solve global problems that have domestic origins. The main reason for this is that government networks involve directly the participation and the credibility of the government officials who must ultimately be responsible for addressing those common problems at the local level.

Slaughter also remarks that government networks, both as they exist now and as they could exist, exercise different types of power to achieve outcomes. Government networks have access to traditional coercive power (based on 'hard law'). Consequently, she argues that the key role of national government officials in government networks means that when a decision is made and that decision requires implementation, the power to implement already exists at the national level. However, she also recognises that most of the work of government networks depends on 'soft-law' power and, hence, suggests that 'An effective world order needs to harness every kind of power available'.105

\footnotetext{
104 Slaughter uses a board concept of a 'network' in order to capture all the different ways that individual government institutions are interacting with their counterparts either abroad or above them, alongside more traditional state-to-state interactions. Anne-Marie Slaughter, A New World Order (Princeton University Press, 2005) 14.

105 ibid, 27.
} 
It can be argued that using Slaughter's terminology, 'government networks' in central banking exist in the formal and informal international institutions and fora in which central banks participate (most notably, IMF, FSB and BIS). ${ }^{106}$ As argued elsewhere in this book, especially in this chapter, central bank diplomacy (based on soft-law commitments) is at the core of such government networks through relationship-building initiatives and information exchange. In concordance with Slaughter, effective central banking cooperation needs to harness the commitments assumed at the government networks. It is here that Common Concern can enable the implementation of such global commitments with the new 'obligation to act' at the domestic level of governance. The adoption at the national level of international standards, like the ones sponsored by the G2o and driven by the FSB, is a successful example on this point. Also, the core principles issued by the International Organisation of Securities Commissions (IOSCO) on securities regulation and the BCBS for banking - while not mandatory - are widely adopted at the national level. The proposed formulation of Common Concern, as a legal doctrine, triggers this enhanced central banking cooperation which then flows into the other aspects of homework and compliance.

\section{Conclusion}

The recognition of global monetary stability as a Common Concern would imply a reinforcement of the role of the IMF as the central international monetary institution from a top-down perspective. In spite of the fact that the regulatory function in global monetary affairs is shared by a number of formal and informal international standard-setters, including most notably the FSB and BIS, the IMF keeps the lead as claimed in this chapter. As asserted by Lastra:

The IMF is the only institution (other than the BIS and the WTO) that has international legitimacy, an array of tools (surveillance, conditional financial assistance and technical assistance), appropriate financial resources and staffing to assume a formal role as global financial authority. Other informal international standard setters, such as the FSB, the вСвS, or IOSCO, can continue with their rule-making role, but only the Fund can effectively contribute to the enforcement of those standards through its surveillance function. ${ }^{107}$

\footnotetext{
106 See the graphic of the 'International Financial Architecture' in chapter 4, Annex I of this book.

107 Lastra, International Financial and Monetary Law (n 7) 551.
} 
The main reason for this is that the Fund's key surveillance function enables it to monitor the member states' compliance with rules and standards and provide incentives for members to comply with them. Also, beyond bilateral surveillance that is performed by individual countries, the IMF performs multilateral surveillance of the global economy, thus helping to identify the impact domestic policies may have on other countries and the global economy. ${ }^{108}$ This analysis may assist with the allocation of burden-sharing of the shared but differentiated responsibilities proposed under the principle of Common Concern.

Notwithstanding the key role of the Fund's surveillance in crisis prevention and enhanced international cooperation, all policy recommendations made in the context of IMF surveillance are of an advisory nature and non-mandatory. Therefore, the bottom-up perspective acquires relevance in the pursuit of a Common Concern of global monetary stability. As remarked by Gopinath, recently-appointed chief economist at the IMF, cross-border cooperation efforts among countries from a domestic level approach are welcome developments to support the well-functioning of the international system:

It is then all the more important for countries to cooperate on financial regulation, to strengthen the global safety net, and to reduce the stigma attached to the lender of last resort role of the IMF. The creation of regional monetary funds like the European Stability Mechanism (ESB) set up in 2012, the Chiang Mai Initiative Multilateralization (СMIM) in 2012, BRICS Contingent Reserve Arrangement (CRA) in 2014 and other smaller regional arrangements that taken together have committed resources of US 1.3 trillion dollars similar to that of the IMF (Denbee et al. (2016)) are welcome developments that complement the IMF in supporting a well functioning international monetary and financial system. ${ }^{109}$

Consequently, the enhanced duty to cooperate proposed by Common Concern would have a positive impact on the promotion of international monetary stability both from a top-down and bottom-up approach. However, the efficacy of such enhanced duty would still depend on the IMF member states' willingness

\footnotetext{
108 'IM F Surveillance' (2021) < www.imf.org/en/About/Factsheets/IMF-Surveillance> accessed 21 October 2021.

109 Gita Gopinath, 'Rethinking International Macroeconomic Policy' (Conference on 'Rethinking Macroeconomic Policy IV', Peterson Institute on International Economics, 25 October 2017) <https://scholar.harvard.edu/files/gopinath/files/openeconomypolicyıo 317.pdf $>$ accessed 21 October 2021.
} 
to enhance the Fund's mandate on the premises of Common Concern and also on each state's readiness to engage in further cross-border cooperation under the guidance of the potential principle of Common Concern. Hence, it is under these circumstances that the new obligation to act as proposed by Common Concern acquires relevance.

\section{Annex I - International Financial Architecture}

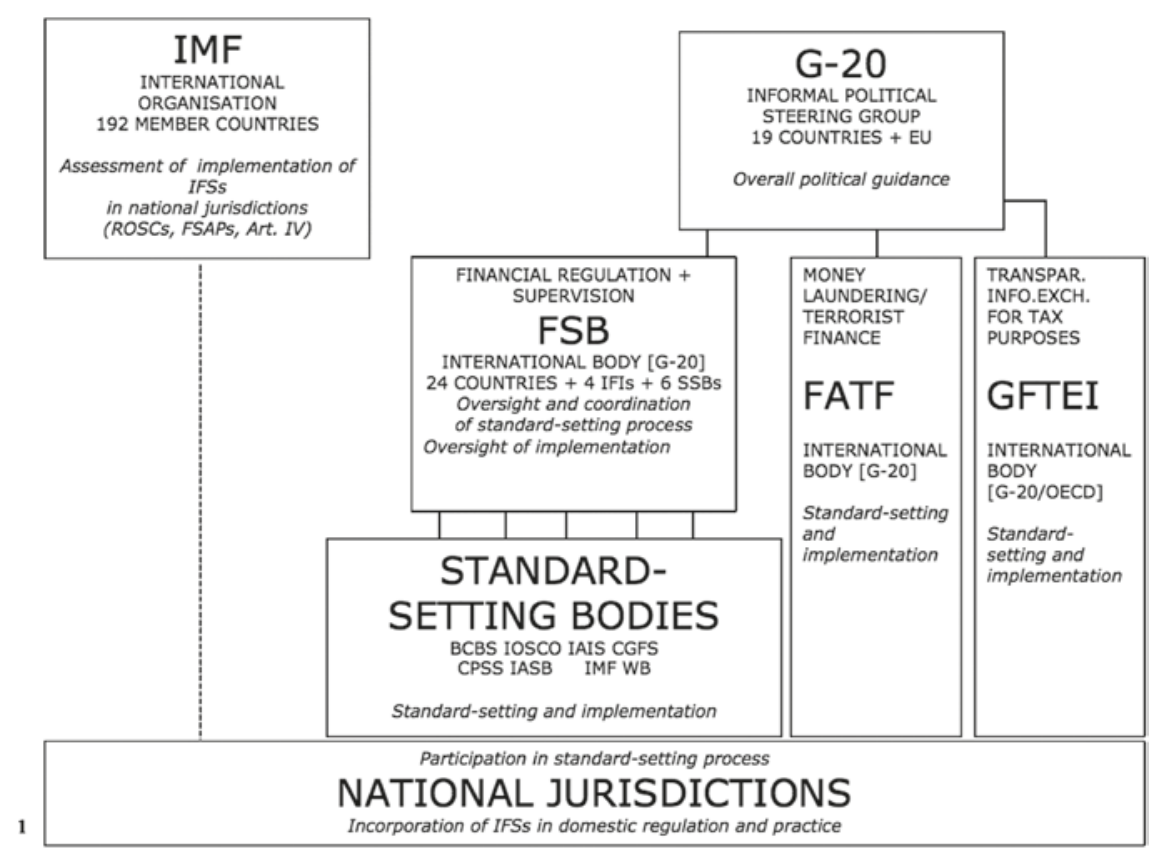

Source: Mario Giovanoli, 'A New Architecture for the Global Financial Markets: Legal Aspects of International Financial Standards Setting' in Mario Giovanoli (ed), International Monetary Law: Issues for the New Millennium (OUP 2000) 38 . 